\title{
Original article (short paper) \\ Blood lactate minimum of rats during swimming test using three incremental stages
}

\author{
Mariana de Souza Sena \\ Universidade Federal de Mato Grosso, Cuiabá, MT, Brazil \\ Roberto Carlos Vieira Junior \\ Universidade do Estado de Mato Grosso, Cáceres, MT, Brazil \\ Cássio Charnoski Rubim \\ Universidade Federal de Mato Grosso, Cuiabá, MT, Brazil \\ Thiago da Rosa Lima \\ Centro Universitário de Várzea Grande, Várzea Grande, MT, Brazil \\ Joice Cristina dos Santos Trombeta \\ Universidade Estadual de Mato Grosso, Diamantino, MT, Brazil \\ Alesandro Garcia \\ Universidade Estadual de Maringá, Maringá, PR, Brazil \\ Jonato Prestes \\ Ramires Alsamir Tibana \\ Universidade Católica de Brasília, Distrito Federal, Brazil \\ Fabrício Azevedo Voltarelli \\ Universidade Federal de Mato Grosso, Cuiabá, MT, Brazil
}

\begin{abstract}
The purpose of this study was to determine the lactate minimum intensity (LMI) by swimming LACmin test using three incremental stages $\left(\mathrm{LACmin}_{\text {test } 3}\right)$ and to evaluate its sensitivity to changes in aerobic fitness (AF). Twenty Wistar rats performed: $\mathrm{LACmin}_{\text {test }}$ (1): induction of hyperlactacidemia and incremental phase $(4 \%, 5 \%$ and $6.5 \%$ of bw); Constant loads tests on (2) and above (3) the LMI. Half of the animals were subjected to training with the individual LMI and the tests were performed again. The mean exercise load in $\mathrm{LACmin}_{\text {test } 3}$ was $5.04 \pm 0.13 \%$ bw at 5.08 $\pm 0.55 \mathrm{mmol} \mathrm{L}^{-1}$ blood lactate minimum (BLM). There was a stabilize and disproportionate increase of blood lactate in tests 2 and 3, respectively. After the training period, the mean BLM was lower in the trained animals. The LACmin ${ }_{\text {test } 3}$ seems to be a good indicator of LMI and responsive to changes in AF in rats subjected to swim training.
\end{abstract}

Keywords: minimum blood lactate test, three incremental stages, rats, swimming

Resumo - "Lactato sanguíneo mínimo de ratos durante teste de natação usando três etapas incrementais." O objetivo deste estudo foi determinar a intensidade no lactato mínimo (ILM) pelo LACmin ${ }_{\text {teste }}$ usando três estágios incrementais $\left(\mathrm{LACmin}_{\text {teste } 3}\right)$ e avaliar sua sensibilidade às alterações do condicionamento aeróbio (CA). Vinte ratos realizaram: LACmin $_{\text {teste }}$ (1): indução da hiperlactacidemia e fase incremental (4\%, 5\% e 6,5\% do pc); Testes de cargas constantes equivalentes (2) e acima (3) da ILM. Metade dos animais foi submetida ao treinamento físico na ILM individual e os testes foram efetuados novamente. A sobrecarga média no $\mathrm{LACmin}_{\text {test } 3}$ foi $5,04 \pm 0,13 \%$ pc à $5,08 \pm 0,55 \mathrm{mmol} \mathrm{L}^{-1}$ de lactato sanguíneo mínimo (LSM). Houve estabilização e aumento desproporcional do lactato sanguíneo nos testes 2 e 3 , respectivamente. Após o período de treinamento, o LSM médio foi menor no grupo treinado. O LACmin ${ }_{\text {teste3 }}$ parece ser um bom indicador da ILM e responsivo às mudanças no CA em ratos treinados por natação.

Palavras-chave: teste do lactato sanguíneo mínimo, três estágios incrementais, ratos, natação

Resumen - “Lactato sanguíneo mínimo de ratas durante la prueba de natación con tres pasos incrementales.” Determinar la intensidad del lactato mínimo (ILM) por LACmintest incremental mediante tres etapas graduales (LACmintest3) y 
evaluar su sensibilidad a los cambios en condiciones aerobias (CA). Veinte ratas realizaron: LACmin $_{\text {test3 }}$ (1): inducción de hiperlactacidemia y fase incremental (4 \%, 5\% y 6,5\% de pc); pruebas de cargas constantes equivalente (2) y arriba (3) de la ILM. Mitad de los animales fueron sometidos a entrenamiento físico con la persona carga equivalente a la ILM y las pruebas se realizaron nuevamente. La carga media en $\mathrm{LACmin}_{\text {test } 3}$ fue 5,04 $\pm 0,13 \%$ pc a 5,08 $\pm 0,55$ mmol L- 1 de lactato mínimo en la sangre (LMS). Se observó una estabilización y desproporcionado aumento de lactato sanguíneo en las pruebas 2 y 3 , respectivamente. Después del período de entrenamiento físico, la media fue menor en el grupo entrenado. LACmin ${ }_{\text {test } 3}$ resultó ser un buen indicador de la ILM y sensible a los cambios que se producen en el CA en ratas entrenadas por nadar.

Palabras claves: Prueba de lactato sanguíneo mínimo, tres etapas graduales, las ratas, natación

\section{Introduction}

The lactate minimum test $\left(\mathrm{LACmin}_{\text {test }}\right)$, which consists of an effort to induce hyperlactatemia followed by an incremental test, have been shown to be reproducible (Dotan et al., 2011; Morel \& Zagatto, 2008), and reliable (Ribeiro, Balikian, Malachias, \& Baldissera, 2003; Smith, Balmer, Coleman, Bird, \& Davison, 2002) for estimating maximal lactate steady state (MLSS) intensity, which is considered as the gold standard procedure in the aerobic endurance evaluation.

Blood lactate concentrations measured during the incremen-

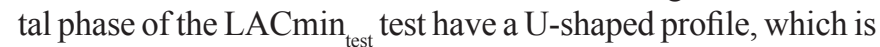
the lactate minimum intensity (LMI), corresponding to the lowest lactate value (minimum point); this is considered to be the highest workload, at which a dynamic balance occurs between lactate production and removal. The minimum lactate point, called blood lactate minimum (BLM), in the lactate-exercise intensity relationship for LMI determination can be obtained visually (Simões, Campbell, Kokubun, Denadai, \& Baldissera, 1999) or by mathematical adjustment (Myagi, Leite, \& Zagatto, 2013; Ribeiro, Gonçalves, Kater, Lima, \& Gobatto, 2009).

In humans, it was reported that the method of hyperlactacidemia induction does not affect the LMI (Smith et al., 2002). On the other hand, Zagatto et al. (2014) verified that the mode of induction of hiperlactacidemia significantly affects the $\mathrm{pH}$, blood lactate, the [HCO3] and, consequently, the LMI, as well as the physiological parameters related to it. Thus, these findings confirm the hypothesis that LMI could be affected by the induction exercise mode, mainly by pronounced acidosis, and that the hyperlactacidemia induction mode must be chosen carefully.

In rats, Araújo, Papoti, Manchado, Mello and Gobatto (2007) evaluated 4 different induction protocols of hyperlactacidemia, and observed that the induction method performed from two swimming sessions at $13 \%$ bw $(1 \mathrm{st}=30 \mathrm{~s} ; 2 \mathrm{nd}=$ up to exhaustion [tlim]), separated by 30 seconds of interval, was the one that has been more successful (91\%) for identifying MLSS in sedentary rats. Beck, Araújo and Gobatto (2012), who also used rats during $\mathrm{LACmin}_{\text {test }}$ swimming, observed similar results to those by Araújo et al. (2007) and proved the effectiveness of the method.

LACmin $_{\text {test }}$ require different blood samples and this feature makes the test more costly financially, and it requires access to the tail end of the animal several times to obtain blood; this is an important limitation. Accordingly, Sotero, Campbell, Pardono, Puga, and Simões (2007), in a study with humans, investigated different methods of determining the LMI in adults with reduced blood collections and found no differences between the intensities obtained in these tests and in the MLSS test.

Based on these results, the authors replicated the study with adolescents, in which it was possible to identify the velocity corresponding to LMI with only three incremental stages, thus validating the protocol for humans (Sotero et al., 2011). However, there are no studies in the literature that determined the LMI of rats during swimming exercise using only three incremental stages and its potential to predict the MLSS.

Thus, the present study aimed to: 1) determine the LMI by LACmin $_{\text {test }}$ composed of three incremental stages $\left(\mathrm{LACmin}_{\text {test } 3}\right)$; 2) verify the capability of the LACmin test $3_{\text {to }}$ to predict MLSS in rats; and 3) assess the sensitivity of $\mathrm{LACmin}_{\text {test } 3}$ to changes in aerobic fitness of rats subjected to 8 weeks of physical training.

Our initial hypothesis is that it is possible to determine the LMI using $\mathrm{LACmin}_{\text {test3 }}$ and that this test is sensitive to changes in aerobic fitness of rats subjected to swimming exercise training for 8 weeks.

\section{Methods}

\section{Animals}

Twenty male Wistar rats (90 days of age at the beginning of the experiment), from the Central Animal House of Federal University of Mato Grosso, Cuiabá, MT, Brazil, were used. The animals were kept in collective cages ( 5 animals per cage) under standardized conditions (22 $\pm 2 \mathrm{C}, 12$-hour light/ dark cycle, with water ad libitum and food (commercial rodent chow Presence $($ ) $)$ on the premises of the Animal Laboratory Experimentation and Exercise of NAFIMES /FEF/UFMT. The study was conducted in accordance with the ethical principles of animal experimentation according to the Brazilian College of Animal Experimentation (COBEA) and approved by the Animal Research Ethics Committee (CEPA) of the Federal University of Mato Grosso (Protocol number 23108.002938/13-0).

\section{Adaptation to water environment and exercise}

All animals were adapted to the water environment and exercise load before the tests. Adaptation consisted of placing the animals in contact with the water depth ( $45 \mathrm{~cm}$ deep) at a temperature of $32 \pm 1^{\circ} \mathrm{C}$, for 3 weeks, 5 days per week. In the first two weeks of adaptation, the rats swam for 60 minutes without overload. In week 3 , the rats carried out load corresponding to $5 \%$ bw for 15 minutes 
in order to familiarize them with the apparatus (lead inserted in sealed bags with Velcro ${ }^{\circledR}$ (Velcro Industries Inc., Manchester, NH, USA) and tied to the chest with the aid of a rubber band).

After the period of adaptation, the rats were subjected to the following exercises, allowing an interval of $48 \mathrm{~h}$ between each test.

\section{Lactate minimum test using three incremental stages (LACmin test 3$)$}

The LACmin test3 consisted of two sessions of swimming at $13 \%$ bw to induce hyperlactacidemia, $\left(1^{\text {st }}=30 \mathrm{~s} ;=2^{\text {nd }}\right.$ until exhaustion [tlim]) separated by 30s intervals (Araújo et al., 2007); the blood lactate peak concentration $\left(\mathrm{mmol} \mathrm{L}^{-1}\right)$ was collected after 9 minutes of rest (Voltarelli et al., 2002). The incremental phase

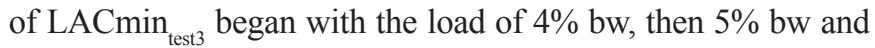
$6.5 \%$ bw, and the load was changed every 5 minutes of exercise.

In every rest and load change, blood samples $(25 \mu \mathrm{l})$ were collected from the tail end of the animal, for determining the concentration of lactate (YSL ${ }^{\circledR}$ Model 2700 Select Biochemistry Analyzer, Yellow Springs, OH, USA). The blood lactate curve versus workload was obtained by polynomial fit of $2^{\text {nd }}$ degree $\left(\right.$ Excel $^{\circledR}$ Microsoft Corporation, New York, NY, USA). The function analysis generated the lowest concentration value of blood lactate (BLM) and corresponding workload, indicating the LMI of each animal (Voltarelli et al., 2002, 2004, 2007).

\section{Swimming test with constant load at LMI}

Tests of 20 minutes of swimming, where animals bore constant load (individual) at LMI obtained by LACmin ${ }_{\text {teste3}}$, was performed. Before beginning the test (rest) and every 5 minutes of exercise, blood samples $(25 \mu \mathrm{l})$ were collected to determine blood lactate by means of the electrochemical analysis equipment (YSL ${ }^{\circledR}$ Model 2700 Select Biochemistry Analyzer, Yellow Springs, OH, USA).

\section{Swimming test with constant load above LMI}

For this test, animals swam with constant load (individual) above LMI obtained by LACmin test3 $_{\text {for }} 20$ minutes. This test was conducted to determine if the intensity of exercise greater than LMI would cause disproportionate increase in blood lactate of the animals (Gobatto et al., 2001; Voltarelli et al., 2002). The test procedures were the same as performed in the preceding item, but using constant load of $1.5 \%$ bw above LMI.

\section{Physical training}

After the tests, half of the animals underwent swimming physical training in proper swimming pool with water at $32 \pm$ $1^{\circ} \mathrm{C}$ for 60 minutes, 5 days per week for 8 weeks and bearing individual overloads at LMI obtained by $\mathrm{LACmin}_{\text {test3 }}$; adjustments of loads $(\%$ bw) were performed three times per week. The animals underwent training in the morning (beginning at $9 \mathrm{~h} 00 \mathrm{~min}$ ). Thus, two experimental groups were formed as follows:

- $\quad$ Sedentary group $(\mathrm{S}, n=10)$ rats kept sedentary throughout the experimental period;

- $\quad$ Trained Group (T, $n=10)$ : rats subjected to swimming physical training with load at LMI obtained by LACmin $_{\text {test3. }}$.

Animals (S and T groups) were weighed at the beginning of each week (group $\mathrm{T}$ with two additional weighing, one in middle and one at the end of the week for load adjustment; \% bw) and the food intake of each group ( $\mathrm{g}$ of feed / $100 \mathrm{~g}$ body weight) were calculated weekly ( 24 hours of ingestion per cage) and expressed in grams.

At the end of the experimental period, the LACmin ${ }_{\text {test3 }}$ and tests with constant load were again performed.

Prior to testing, the rats belonging to $\mathrm{S}$ group were readapted to the water environment and swimming exercise, which was to put them in contact with the deep water ( $45 \mathrm{~cm}$ depth) at the temperature of $32 \pm 1^{\circ} \mathrm{C}$ for 4 days. In the first three days of readaptation, the rats swam for 30 minutes without overload. On the 4 th day, the rats bore load corresponding to $5 \%$ of the bw for 10 minutes in order to re-familiarize them with the apparatus.

After readaptation to the water environment of the $\mathrm{S}$ group, LACmin $_{\text {test3 }}$, as well as constant fixed load tests, were again performed with the $\mathrm{S}(n=8)$ and $\mathrm{T}(n=9)$ groups. The reduced sampling in $\mathrm{S}$ and $\mathrm{T}$ groups occurred during this period of rehabilitation and during $\mathrm{LACmin}_{\text {test3 }}$ after physical training, respectively.

Importantly, the protocols of adaptation to the water and swimming exercise were performed in a specific glass pool containing 14 bays (MBS®, São Paulo-SP, Brazil).

\section{Statistical analysis}

The results were expressed as mean \pm standard deviation (SD) and analyzed by Student's $t$ test in order to check the difference between the mean concentration of LA and exercise load during $\mathrm{LACmin}_{\text {test3 }}$ and constant load tests performed after the end of the experimental period between the $\mathrm{S}$ and $\mathrm{T}$ groups (Student $t$-test unpaired). Analyses were performed using Microsoft Excel ${ }^{\circledR}$ Microsoft Corporation, New York, NY, USA) and $p$ values $<.05$ indicated significance.

\section{Results}

\section{Tests performed in the physical pre-training period of} swimming

\section{$L_{A C \text { min }_{\text {test } 3}}$}

The concentrations of blood lactate and loads equivalent of a single rat is given as an example, during the $\mathrm{LACmin}_{\text {teste } 3}$ as presented in Figure 1. The LMI was $4.94 \%$ bw at $4.50 \mathrm{mmo.L}^{-1}$ of BLM. 


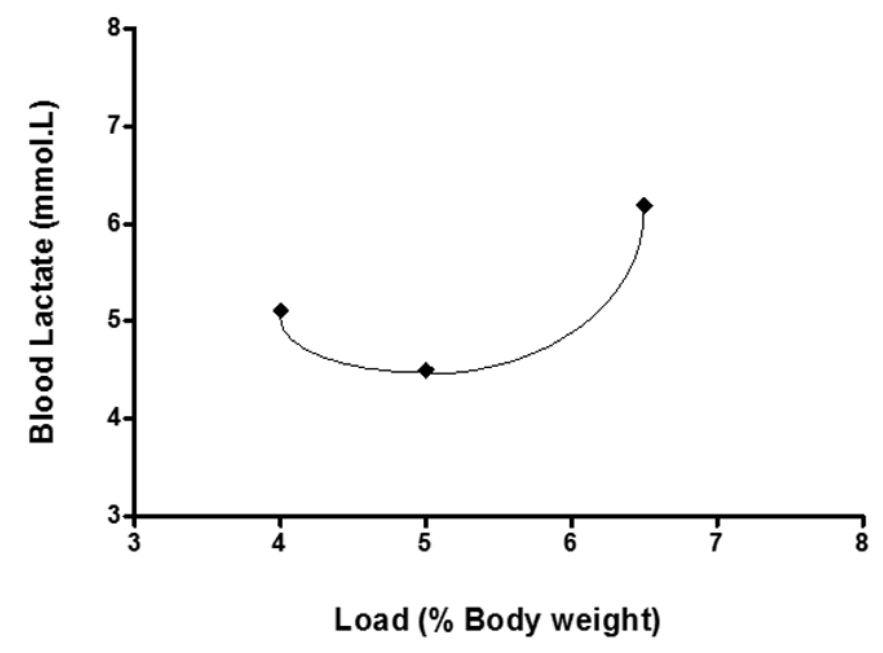

Figure 1. Blood lactate concentration curve versus workload of one

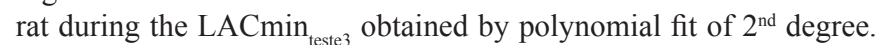
The equation $y=0.6947 x^{2}-6.862 x+21.443$ enabled the calculation of the BLM concentration and its workload ( $\% \mathrm{bw})$.

A

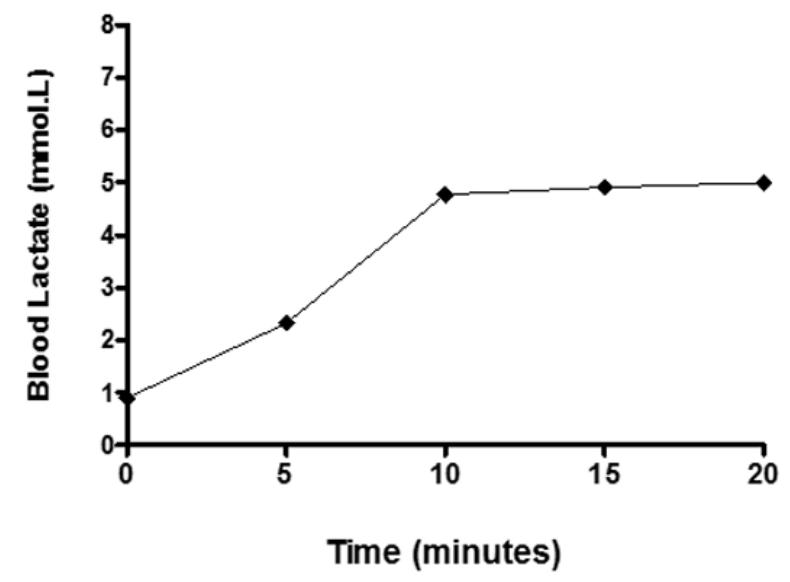

For all animals $(n=20)$, the LMI was $5.04 \pm 0.13 \%$ bw and the BLM equals to $5.08 \pm 0.55$ mmol. $\mathrm{L}^{-1}$.

\section{Swim test with constant load}

Figure 2A indicates stabilization of the concentration of blood lactate of a single rat (same as rat in Figure 1) from 10 minutes of exercise; the mean stabilization (taking into account the 10 minutes, 15 and 20) was $4.90 \pm 0.11 \mathrm{mmol} \mathrm{L}^{-1}$; Figure 2B shows a disproportionate blood lactate increase with respect to time (for 20 minutes) during the same test with rat carrying out constant load above LMI.

Taking into account the 10,15 and 20 minutes, the mean concentration of blood lactate $(n=20)$ was $5.47 \pm 0.60 \mathrm{mmol} \mathrm{L}^{-1}$, similar to the mean BLM obtained in LACmin ${ }_{\text {test }}(p$ value $<.01)$.

In the test where rats were subjected to the exercise load of $1.5 \%$ bw above the LMI, the mean blood lactate concentrations of rats that completed the test were $0.92 \pm 0.04 ; 3.17 \pm 0.20$; $4.80 \pm 0.34 ; 6.11 \pm 0.37 ; 7.51 \pm 0.35 \mathrm{mmol} \mathrm{L}^{-1}$ for the periods of $0,5,10,15$ and 20 minutes, respectively. It is worth mentioning that only 5 rats finished the test.

B

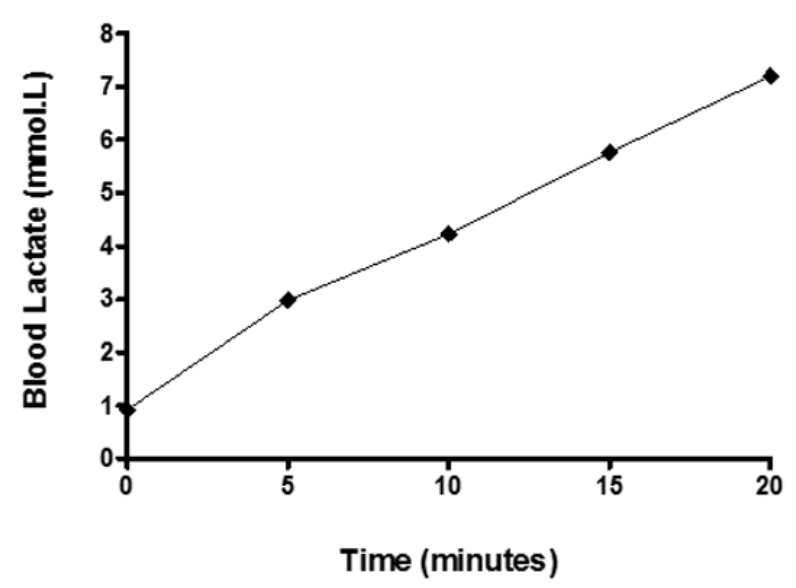

Figure 2. Blood lactate concentration vs exercise time of one rat (same as rat in Figure 1) during constant load test bore load (individual) at LMI (A) and; carrying out constant load above LMI obtained by LACmin teste3 $_{\text {(B) }}$.

Tests performed after 8 weeks of swimming exercise training

$$
\text { LACmin }_{\text {test3 }}
$$

Figure 3 shows the concentrations of blood lactate of one rat during the $\mathrm{LACmin}_{\text {test3 }}$ after physical training for 8 weeks (same as rat in Figure 1).

The LMI of this animal was obtained on load of $5.11 \%$ bw at $3.98 \mathrm{mmol} . \mathrm{L}^{-1}$ of BLM.
For all animals belonging to T group $(n=9)$, the LMI was $5.06 \pm 0.12 \%$ bw at $4.16 \pm 0.23 \mathrm{mmol} . \mathrm{L}^{-1}$ of BLM.

Figure 4 shows the concentrations of blood lactate versus workload of only one rat during $\mathrm{LACmin}_{\text {test } 3}$ belonging to the $\mathrm{S}$ group at the end of the experimental period. The LMI was $5.17 \%$ bw at $5.29 \mathrm{mmol}^{-1} \mathrm{~L}^{-1}$ of BLM.

For all animals belonging to $\mathrm{S}$ group $(n=8)$, the LMI was $5.00 \pm 0.15 \%$ bw and BLM at $6.21 \pm 1.03$ mmol. $\mathrm{L}^{-1}$ for that rats which completed the test (5 animals). 


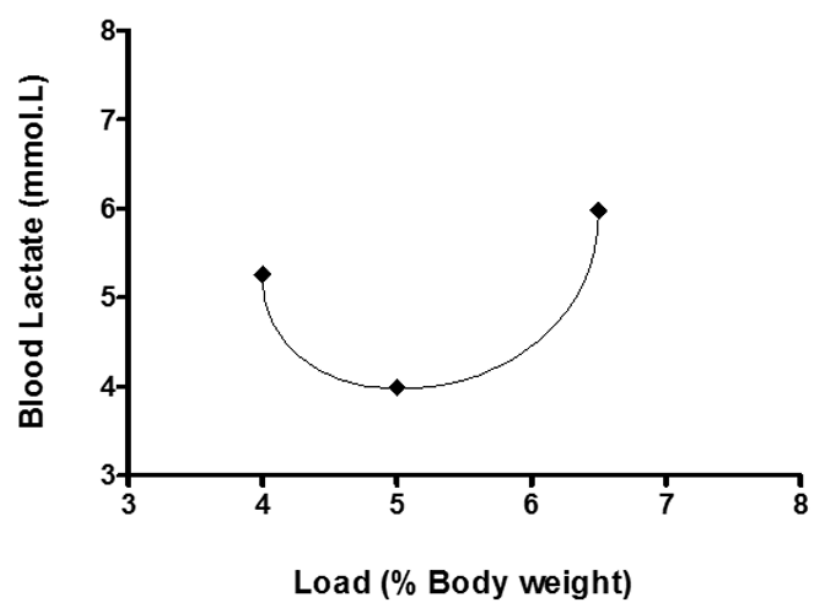

Figure 3. Blood lactate concentration curve versus workload of one rat (T group) during the post-training LACmin $_{\text {test3. }}$ The equation $y=$ $1.0387 x^{2}-10.618 x+31.113$ enabled the calculation of the BLM concentration and its workload $(\% \mathrm{bw})$.

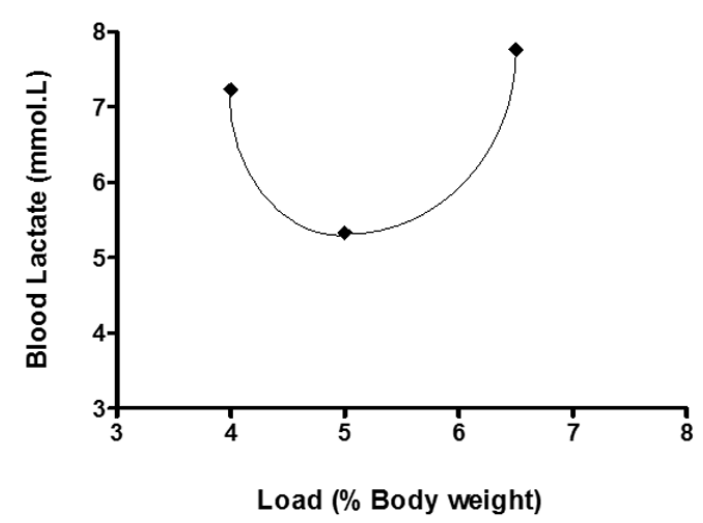

Figure 4. Blood lactate concentration curve versus workload of one rat (S group) during the post-training $\mathrm{LACmin}_{\text {test3. }}$ The equation $y=$ $1.408 x^{2}-14.572 x+42.99$ enabled the calculation of the BLM concentration and its workload (\% bw).

Table 1 shows the mean concentration of BLM and exercise loads equivalent to LMI for animals that completed the LACmin $_{\text {test3 }}$ after the experimental period in both groups.

Table 1. Means values of BLM concentrations (mmol. $\left.\mathrm{L}^{-1}\right)$ and exercise loads $\left(\mathrm{mmol}^{-1} \mathrm{~L}^{-1}\right)$ obtained by LACmin ${ }_{\text {test3 }}$ after the experimental period in both groups (S group $n=5$ and T group $n=9)$ (mean $\pm \mathrm{SD}$; values with $p<.05$ indicate significance; Student $t$-test unpaired).

\begin{tabular}{cccr}
\hline & S group $(\boldsymbol{n}=\mathbf{5})$ & T group $(\boldsymbol{n}=\mathbf{9})$ & $\boldsymbol{p}$-value \\
\hline LMI & $5.00 \pm 0.15$ & $5.06 \pm 0.12$ & .43 \\
$\begin{array}{c}\text { BLM } \\
\text { concentration }\end{array}$ & $6.21 \pm 1.03$ & $4.16 \pm 0.23$ & .01 \\
\hline
\end{tabular}

\section{Swimming test with constant load at LMI}

Figure 5 shows blood lactate levels of only one rat (same as Figure 3), after physical training of 8 weeks, during swimming test with constant load at LMI; Blood lactate stabilization was observed from 10 minutes of exercise in the mean value of $3.86 \pm 0.06 \mathrm{mmol} \mathrm{L}^{-1}$ (taking into account the 10, 15 and 20 minutes). The same occurred with the animal (as in Figure 4) that remained sedentary for 8 weeks $\left(6.01 \pm 0.27 \mathrm{mmol} \mathrm{L}^{-1}\right)$.

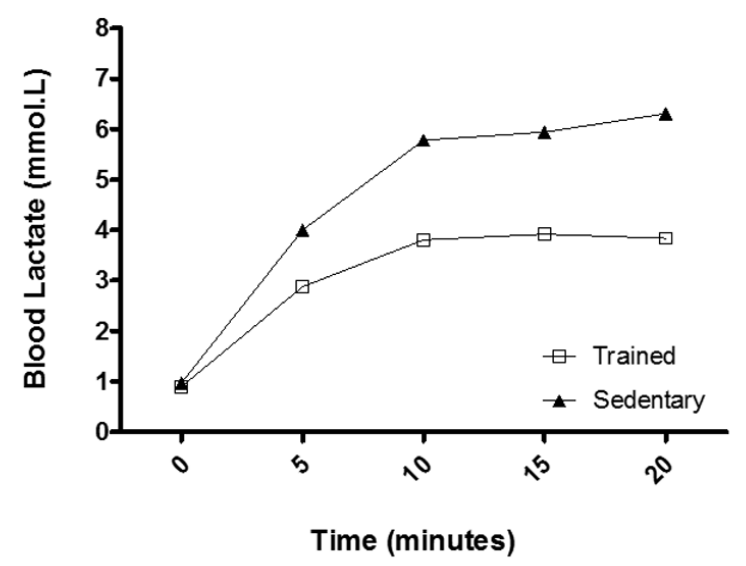

Figure 5. Blood lactate concentration vs exercise time of one rat after physical training and one rat that remained sedentary ( 8 weeks) during constant load test bore load (individual) at LMI obtained by LACmin ${ }_{\text {teste3. }}$

The mean concentration of stabilization $(10,15$ and 20 minutes) of T group ( $n=9)$ was obtained at $4.12 \pm 0.38 \mathrm{mmol}$ $\mathrm{L}^{-1}$ of blood lactate. With regard to $\mathrm{S}$ group $(n=5)$, the mean value was $6.62 \pm 0.88 \mathrm{mmol} \mathrm{L}^{-1}(p<.01$ compared to $\mathrm{T})$.

\section{Swimming test with constant load above LMI}

Figure 6 shows a disproportionate increase in the blood lactate concentration with respect to time (over 20 minutes) of only one rat (same as Figure 3) after physical training for 8 weeks and one (the only rat that completed the test) kept inactive as an example. It is important to state that no stabilization of the blood lactate was observed in any of the animal evaluated.

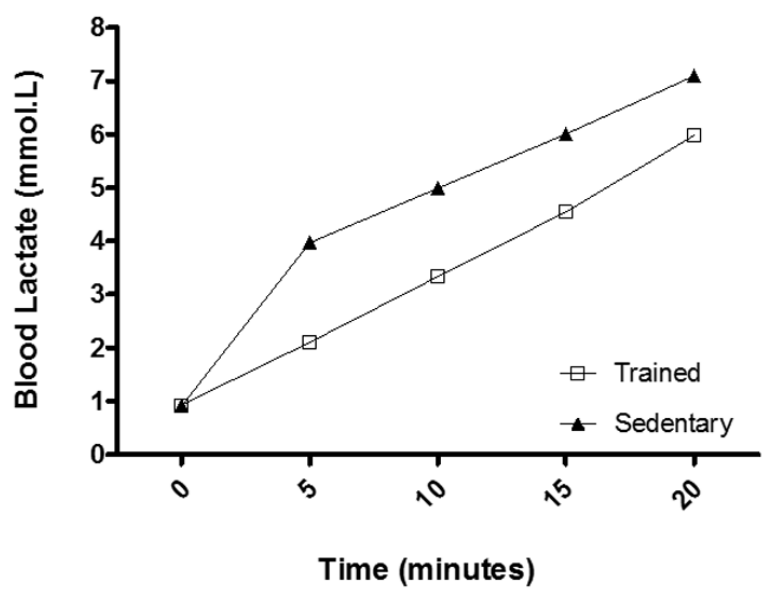

Figure 6. Blood lactate concentration vs exercise time of one rat after physical training (same as Figure 3 and 5) and one (the only rat that completed the test) remained sedentary ( 8 weeks) during constant load test carrying out load above LMI obtained by post-training LACmin $_{\text {test3. }}$. 
Table 2 shows the values of weight gain and the food intake of rats belonging to $\mathrm{S}$ and $\mathrm{T}$ groups during the experimental period. There was no statistical difference.

Table 2. Body weight gain (g) and individual food intake ( $\mathrm{g}$ of feed / $100 \mathrm{~g}$ body weight) of rats ( $\mathrm{S}$ and $\mathrm{T}$ groups) during the experimental period (mean $\pm \mathrm{SD}$; values with $p<.05$ indicate significance; Student $t$-test unpaired).

\begin{tabular}{cccc}
\hline Variables & S group $(\boldsymbol{n}=\mathbf{8})$ & T group $(\boldsymbol{n}=\mathbf{9})$ & $\boldsymbol{p}$-value \\
\hline Weight gain $(\mathrm{g})$ & $74.5 \pm 19.91$ & $70.7 \pm 16.91$ & .68 \\
Food intake $(\mathrm{g})$ & $6.2 \pm 0.35$ & $6.4 \pm 0.47$ & .65 \\
\hline
\end{tabular}

\section{Discussion}

To the best of our knowledge, this is the first study to investigate the effects of LACmin ${ }_{\text {test }}$ with three incremental stages $\left(\mathrm{LACmin}_{\text {test3 }}\right)$ in rats subjected to swimming exercise for determining LMI. Our results showed that LACmin ${ }_{\text {test3 }}$ was sensitive to changes in aerobic fitness of rats subjected to 8 weeks of physical training with regard to blood lactate concentration.

Figure 1 shows, as a way of example, the LMI of only one rat obtained with a load of $4.50 \%$ bw at $4.94 \mathrm{mmol}^{-L^{-1}}$ of BLM, thus indicating the possibility of obtaining the curve for calculating these values with the use of only three incremental stages.

The mean loads equivalent to LMI and concentrations of BLM for all rats $(n=20)$ were $5.04 \pm 0.13 \%$ bw and $5.08 \pm$ $0.55 \mathrm{mmol} \mathrm{L}^{-1}$, respectively. The LMI obtained was similar to others observed in previous investigations (Voltarelli et al., 2002; Voltarelli et al. 2004). Despite the similarity in relation to the exercise loads, BLM levels obtained from previous studies were higher than those achieved in this study, supporting the hypothesis that BLM values can be protocol-dependent, since the method of induction of hyperlactacidemia in the works of Voltarelli et al. $(2002,2004)$ was by jumping into water $(30 \mathrm{~s}$ jumps in water followed by 30 seconds of rest, to complete a total of 6 minutes) with load equivalent to $50 \% \mathrm{bw}$.

It is known that different protocols for the induction of hiperlactacidemia alter the values of BLM. Araujo et al. (2007) observed greater success in induction protocols that promoted a lower concentration of BLM, mainly in the protocol that consisted of two swimming sessions with $13 \%$ bw (the first for 30 s and the second up to the point of exhaustion) separated by $30 \mathrm{~s}$ of rest ( $91 \%$ success), being exactly the protocol employed in the present study.

Although we did not observe similar values of BLM, as aforesaid, our results were similar in relation to LMI obtained in studies of Voltarelli et al. (2002, 2004), which was performed with 6 incremental stages in the LACmin test $_{\text {; }}$ this confirms the efficiency of LACmin $_{\text {test3 }}$ in obtaining the LMI with only 3 points of collection in incremental phase of the test. In the present study, it was not possible to perform conventional LACmin for comparison with $\mathrm{LACmin}_{\text {test } 3}$, being this a limitation.

In order to prove the efficiency of the protocol proposed by us in predicting the MLSS, two swimming tests of 20 minutes with individual constant load were performed, one at the LMI

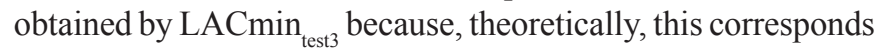

to MLSS intensity (Sotero et al., 2007; Voltarelli et al. 2002, 2004) and one with individual constant load above the LMI

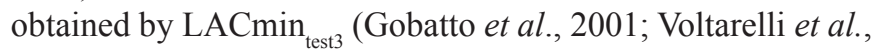
2002).

Figure 2A denotes stabilization in the mean concentration of blood lactate $\left(4.90 \pm 0.11 \mathrm{mmol} \mathrm{L}^{-1}\right)$ of only one rat, as example, from 10 minutes of exercise (taking into account the 10 minutes, 15 and 20). The mean values of blood lactate demonstrated stabilization $\left(5.47 \pm 0.60 \mathrm{mmol} \mathrm{L}^{-1}\right)$ for all animals; this value is similar $(p<.01)$ to the mean BLM obtained

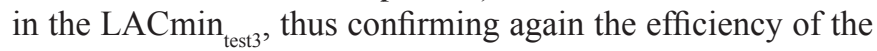
test to determine the LMI.

On the other hand, with respect to the test with the exercise load above $(+1.5 \%$ bw $)$ the LMI, we observed disproportionately increased of blood lactate (Figure 2B), which occurs as a result of an imbalance between production and removal of such substrate. This imbalance leads to fatigue in the animal, which explains, in part, the fact that only 5 rats were able to complete the test. These results agree with those obtained in other studies (Gobatto et al., 2001; Voltarelli et al., 2002, 2004) and confirmed the efficiency of $\mathrm{LACmin}_{\text {test3 }}$ in obtaining the LMI as well as its capability in predicting the MLSS.

Several studies have suggested the use of LMI for improving cardiorespiratory fitness and physical performance, whether in humans (Kinderman et al., 1979; Sjodin \& Jacobs, 1981) or rats (Gobatto et al., 2001; Voltarelli et al., 2002, 2004). For this reason, this study also assessed the effect of physical training on aerobic capacity of rats subjected to LACmin test 3 . .

Figure 3 shows the concentration of BLM $(3.98 \mathrm{mmol}$ $\left.\mathrm{L}^{-1}\right)$ and LMI (5.11\% bw) of only one rat, as example, during

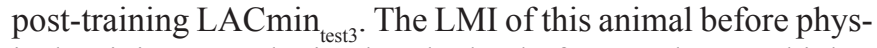
ical training was obtained at the load of $4.94 \%$ bw at a higher BLM concentration ( $4.50 \mathrm{mmol} \mathrm{L}^{-1}$ ) (Figure 1). The opposite was observed in relation to the rat maintained in sedentary situation (Figure 4); the LMI of this animal was initially achieved at a concentration of BLM equal to $4.88 \mathrm{mmol.L}$. $5.34 \%$ bw, and after 8 weeks of inactivity the LMI obtained was $5.17 \%$ bw at $5.29 \mathrm{mmol} \mathrm{L}^{-1}$ of BLM. This occurrence indicated that sedentary lifestyle undermined the aerobic capacity of this animal and that the LACmin test3 $_{\text {. }}$ was able to identify these differences successfully.

Table 1 shows the mean values of BLM and LMI of all rats that were able to complete the post-training LACmin ${ }_{\text {test3 }}$ (Groups $\mathrm{S}$ and $\mathrm{T})$. When compared the mean BLM, we found a lower value obtained by $\mathrm{T}(p=.01)$, which confirms the improvement in aerobic fitness of these animals as well as decrease in aerobic capacity and consequent worsening of the physical performance in the $\mathrm{S}$ group.

In the study performed by Voltarelli et al. (2004), the val-

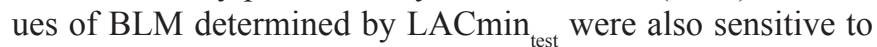
changes in aerobic physical conditioning of animals induced by training, with decreases in the concentrations $(7.39 \pm 0.39$, $6.38 \pm 0.12$ and $5.89 \pm 0.14 \mathrm{mmol} \mathrm{L}^{-1}$ ) observed in sedentary condition, $4^{\text {th }}$ and $8^{\text {th }}$ weeks of training, respectively.

There was no difference between the mean values of LMI

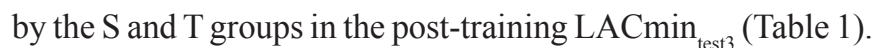
On the other hand, Voltarelli et al. (2004) observed increased 
intensities of exercise $(4.93 \pm 0.07,5.42 \pm 0.01$ and $5.98 \pm 0.02 \%$ bw) in the sedentary situation, 4 and 8 weeks of training, respectively) at LMI after applying $\mathrm{LACmin}_{\text {test }}$ with 6 incremental stages. We suggest that this may be due in part to the non-load adjustment on a week-by-week basis, or at least in the first half of the training period as it was done in the work of Voltarelli et al. (2004). In order to accomplish such adjustment, it would be necessary to perform $\mathrm{LACmin}_{\text {test3 }}$ each week, which would be impractical for us due to the costs generated by collections and determination of blood lactate concentrations. However, this fact should be taken into consideration in future studies, since it can determine the outcome, especially in relation to LMI and not for what seemed, in relation to the concentrations of BLM.

Another explanation for the lack of alteration of LMI in the present study, after 8 weeks of exercise training, may be explained by the question of the nature of the monotonous character of the same, since Araújo et al. (2013a), in an unprecedented manner, observed that the monotonous training did not affect aerobic performance (exercise load) (corroborating our results), decreased anaerobic capacity and also increased the concentration of the enzyme creatine kinase (CK) of the animals. Moreover, the continuous training (and monotonous), in another study (Araújo et al., 2013b), only performed at intensities below the LMI ( $80 \%$ and $90 \%)$ (unlike the present study), increased exercise load at the end of training and, importantly, without altering markers of oxidative stress and muscle damage (CK). It is noteworthy that the same study (Araújo et al., 2013b), an increase stabilization in the exercise load was related to the absolute amount and not the relative ( $\%$ body weight). Thus, the absolute load method seems to be more reliable in indicating adaptations to overload and this is suggested for future studies.

Corroborating again our results as regards the non-modification of the training load (LMI) after physical training, Araújo et al. (2012) observed that even after performing linear periodization (including taper period) there was an increase training load only when the trained animals were compared with the sedentary, denoting difficulty of achieving improvement in aerobic performance of animals subjected to physical training in swimming, independently of the method used.

Tests with constant workload performed after the trial period confirmed the results above. Figure 5 shows that the trained animal showed lower stabilization of the blood lactate mean value $\left(3.86 \pm 0.06 \mathrm{mmol} \mathrm{L}^{-1}\right)$ if compared to sedentary ones $(6.01 \pm$ $\left.0.27 \mathrm{mmol} \mathrm{L}^{-1}\right)$. From the mean values of stabilization, the same occurred (T: $4.12 \pm 0.38, \mathrm{~S}: 6.62 \pm 0.88, p<.01$ ).

In the test conducted with a constant load above LMI, the results obtained in both groups showed a disproportionate increase in the blood lactate for all animals.

Figure 6 demonstrates disproportionate increase in the blood lactate concentration of only one rat (as Figure 3 ) after 8 weeks of physical training, and also one (the one ending the test) rat kept inactive, as example, confirming the difference in blood lactate concentrations between the groups.

The testing of constant load at LMI applied to both groups confirmed the effectiveness of training in reducing blood lactate concentrations in the T group. In the work of Voltarelli et al. (2004), constant load tests carried out confirmed the increase in exercise intensity $(4.93 \pm 0.09,5.42 \pm 0.01$ and $5.98 \pm 0.02 \%$ bw in sedentary situations, 4 and 8 weeks of training, respectively) and decreased concentrations of stabilization of blood lactate $\left(6.66 \pm 0.37,6.10 \pm 0.05\right.$ and $5.51 \pm 0.15 \mathrm{mmol} \mathrm{L}^{-1}$ in sedentary conditions, 4 and 8 weeks of training, respectively) (stabilization after 15 minutes) in the course of 8 weeks physical training.

As general results, there was no difference in weight gain and food intake between the two groups (Table 2). This control was important for evaluating the health of the animals, since they gained weight and ingested food uniformly, regardless of the group evaluated.

Another important question that can help to explain our results referents to no changes of LMI is the body density of the animals, because it is particularly important in longitudinal studies in which the intervention or ageing process can modify the animal's body composition. During the forced swimming exercise, animals swim by vertical propulsion, and loads may be attached to their body to make it more difficult for them to stay on the surface of the water. Despite the acceptance of this test, this methodology may lack precision if it ignores the animal's body density (BD), once is evident that less dense animals have an intrinsic advantage in facilitating floatability, and therefore less dense animals require less effort to stay afloat than more dense animals.

In this sense, dos Reis et al. (2011) verified that older rats presented higher density, which requires more effort to sustain higher water surface, and, therefore, it is possible to underestimate the aerobic endurance (determined, in this case, by LMI as well as BLM) of older rats compared with younger (at the beginning of the experiment) rats. Further studies using LACmin $_{\text {test } 3}$ and body density are necessary in order to better clarify this appointment.

Presenting lower demand for time, cost and fewer incisions in the tail of the animal, the $\mathrm{LACmin}_{\text {test }}$ test used here as a new proposal proved to be a good indicator of LMI in rats, since the results obtained were confirmed by conducting tests of constant loads and, therefore, appeared to predict the MLSS. Even, the LACmin ${ }_{\text {test } 3}$ was sensitive to changes in the aerobic fitness of rats subjected to physical training for 8 weeks with LMI obtained in the test, at least with regard to the observed changes in the concentrations of BLM and blood lactate during the test with constant loads and thus, we recommend its application in rats submitted to swimming exercise not only in eutrophic animals (healthy) but also in animals suffering from diseases such as diabetes mellitus, heart failure, among others, as the reduction from six to three blood samples would be positive in these models.

\section{References}

Araujo, G.G., Papoti, M., Manchado-Gobatto, F.B., \& Mello, M.A.R. (2013a). Monitoring chronic Physical stress using biomarkers, performance protocols and mathematical functions to identify Physiological adaptations in rats. Laboratory Animals, 47, 36-42.

Araujo, G.G., Papoti, M., Delbin, M.A., \& Gobatto, C.A. (2013b). Physiological adaptations during endurance training below 
anaerobic threshold in rats. European Journal of Applied Physiology, 113, 1859-1870.

Araujo, G.G., Papoti, M., Reis, I.G.M., Mello, M.A.R., \& Gobatto, C.A. (2012). Physiological responses during linear periodized training in rats. European Journal of Applied Physiology, 112, 839-852.

Araujo, G.G., Papoti, M., Manchado, F.B., Mello, M.A.R., \& Gobatto, C.A. (2007). Protocols for hyperlactatemia induction in the lactate minimum test adapted to swimming rats. Comparative Biochemistry and Physiology, 148, 888-892.

Bacon, L., \& Kern, M. (1999). Evaluating a test protocol for predicting maximum lactate steady state. Journal of Sports Medicine and Physical Fitness, 39, 300-308.

Baldari, C., \& Guidetti, L. (2000). A simple method for individual anaerobic threshold as a predictor of max lactate steady state. Medicine \& Science in Sports \& Exercise, 32, 1798-1802.

Beck, W.R., Araújo, G.G., \& Gobatto, C.A. (2012). Methods of exercise intensity and lactatemia determination of lactate minimum test in rats. Comparative Biochemistry and Physiology, 8, 113-116.

Beneke, R., Hutler, M., \& Leithauser, R.M. (2000). Maximal lactate steady state independent of performance. Medicine \& Science in Sports \& Exercise, 32, 1135-1139.

Brooks, G.A. (2009). Cell-cell and intracelular lactate shuttles. The Journal of Physiology, 587, 5591-5600.

Carvalho, J.F., Masuda, M.O., \& Pompeu, F.A.M.S. (2005). Method for diagnosis and control of aerobic training in rats based on lactate threshold. Comparative Biochemistry and Physiology, 140, 409-413.

Dotan, R., Zigel, L., Rotstein, A., Greenberg, T., Benyamini, Y., \& Falk, B. (2011). Reliability and validity of the lactate-minimum test. A revisit. Journal of Sports Medicine and Physical Fitness, 51, 42 - 49.

Ferreira, J.C.B, Rolim, N.P.L., Bartholomeu, J.B., Gobatto, C.A., Kokubun, E., \& Brum PC. (2007). Maximal lactate steady state in running mice: Effect of exercise training. Clinical and Experimental Pharmacology and Physiology, 34, 760-765.

Gobatto, C.A., Kokubun, E, Sibuya, C.Y., \& Mello, M.A.R. (1991). Efeitos da desnutrição protéico-calórica e do treinamento físico na produção de ácido lático em ratos machos adultos após testes de cargas progressivas. Resultados preliminares. Ciência e Cultura, 43, 725-726.

Gobatto, C.A., Mello, M.A.R., Sibuya, C.Y, Azevedo, J.R.M., Santos, L.A., \& Kokubun, E. (2001). Maximal lactate steady state in rats submitted to swimming exercise. Comparative Biochemistry and Physiology, 130, 21-27.

Gondim, F.J., Zoppi, C.C., Silva, L.P., \& Macedo, D.V. (2007). Determination of the anaerobic threshold and maximal lactate steady state speed in equines using the lactate minimum speed protocol. Comparative Biochemistry and Physiology, 146, 375-380.

Green, H.J., Hughson, R.L., Orr, G.W., \& Ranney, D.A. (1983). Anaerobic threshold, blood lactate, and muscle metabolites in progressive exercise. Journal of Applied Physiology (Respiratory, Environmental and Exercise Physiology), 54, 1032-1038.

Heck, H., Mader, A., Hess, G., Mucke, S., Muller, R., \& Hollmann, W. (1985). Justification of the 4-mmol/L lactate threshold. International Journal of Sports Medicine, 6, 117-130.

Jones, A.M., \& Carter, H. (2000). The effect of endurance training on parameters of aerobic fitness. Sports Medicine, 29, 373-376.
Jones, A.M., \& Dousty, J.H. (1998). The validity of the lactate minimum test for determination of the maximal lactate steady state and physiological correlates to $8 \mathrm{~km}$ running performance. Medicine \& Science in Sports \& Exercise, 30, 1304-1313.

Kindermann, W., Simon, G., \& Keul, J. (1979). The significance of the aerobicanaerobic transition for the determination of work load intensities during endurance training. European Journal of Applied Physiology, 42, 25-34.

Mader, A., \& Heck, H. (1986). A theory of the metabolic origin of anaerobic threshold. International Journal of Sports Medicine, 7, 45-65.

Manchado, F.B., Gobatto, C.A., Voltarelli, F.A., \& Mello, M.A.R. (2006). Nonexhaustive test for aerobic capacity determination in swimming rats. Applied Physiology, Nutrition, and Metabolism, 31, 731-736.

Myagi, W.E., Leite, J.V.M., \& Zagatto, A.M. (2013). Influence of the selection from incremental stages on lactate minimum intensity: a pilot study. Revista Brasileira de Cineantropometria e Desempenho Humano, 15, 715-725.

Morel, É.A., \& Zagatto, A.M. (2008), Adaptação dos testes de lactato mínimo, potência crítica e limiar anaeróbio para avaliação da transição anaeróbia-anaeróbia em protocolo específico para o tênis de mesa. Revista Brasileira de Medicina do Esporte, 14, 518 - 522.

Palmer, A.S., Potteiger, J.A., Nau, K.L., \& Tong, R.J. (1999). A 1-day maximal lactate steady state assessment protocol for trained runners. Medicine \& Science in Sports \& Exercise, 31, 1336-1341.

Pilis, W., Zarzeczny, R., Langfort, J, Kaciuba-Uscilko, H., Nazar, k., \& Wojtyna, J. (1993). Anaerobic threshold in rats. Comparative Biochemistry and Physiology, 106, 285-289.

Reis, I.G.M., Araujo, G.G., \& Gobatto, C.A. (2011). Maximal lactate steady state in swimming rats by a body density-related method of workload quantification. Comparative Exercise Physiology, 7, 179-184.

Ribeiro, L., Balikian, P., Malachias, P., \& Baldiserra, V. (2003). Stage length, spline function and lactate minimum swimming speed. The Journal of Sports Medicine and Physical Fitness, 43, 312-318.

Ribeiro, L.F., Gonçalves, C.G., Kater, D.P., Lima, M.C., \& Gobatto, C.A. (2009). Influence of recovery manipulation after hyperlactemia induction on the lactate minimum intensity. European Journal of Applied Physiology, 105, 159-165.

Simões, H.G., Campbell, C.S.G., Kokubun, E., Denadai, B.S., \& Baldissera, V. (1999). Blood glucose responses for individual anaerobic threshold and for lactate minimum in trac tests. European Journal of Applied Physiology, 80, 34-40.

Sjodin, B., \& Jacobs, I. (1981). Onset of blood lactate accumulation and marathon running performance. International Journal of Sports Medicine, 2, 23-26.

Smith, M.F., Balmer, J., Coleman, D.A., Bird, S.R., \& Davison, R.C. (2002). Method of lactate elevation does not affect the determination of the lactate minimum. Medicine \& Science in Sports \& Exercise, 34, 1744-1749.

Sotero, R.C., Campbell, C.S.G., Pardono, E., Puga, G.M., \& Simões, H.G. (2007). Polynomial adjustment as a new technique for determination of lactate minimum velocity with reduced blood sampling. Revista Brasileira de Cineantropometria \& Desempenho Humano, 9, 327-332.

Sotero, R.C., Cunha, V.N.C., Madrid, B., Sales, M.M., Moreira, S.E.R., \& Simões, H.G. (2011). Identificação do lactato mínimo 
de corredores adolescentes em teste de pista de três estágios incrementais. Revista Brasileira de Medicina do Esporte, 17, 119-122.

Tegtbur, U., Busse, M.W., \& Braumann, K.M. (1993). Estimation of an individual equilibrium between lactate production and catabolism during exercise. Medicine \& Science in Sports \& Exercise, 25, 620-627.

Voltarelli, F.A., Gobatto, C.A., \& Mello, M.A.R. (2002). Determination of anaerobic threshold in rats using the lactate minimum test. Brazilian Journal of Medical and Biological Research, 35, 1389-1394.

Voltarelli, F.A., Gobatto, C.A., \& Mello, M.A.R. (2007). Determinação da transição metabólica através do teste do lactato mínimo em ratos desnutridos. Revista da Educação Física, 18, 33-39.

Voltarelli, F.A., Mello, M.A.R., \& Gobatto, C.A. (2004). Limiar anaeróbio determinado pelo teste do lactato mínimo em ratos: Efeito dos estoques de glicogênio muscular e do treinamento físico. Revista Portuguesa de Ciências do Desporto, 4, 16-25.

Zagatto, A.M., Padulo, J, Müller, P.T.G., Miyagi, W.E., Malta, E.S., \& Papoti, M. (2014). Hyperlactemia induction modes affect the lactate minimum power and physiological responses in cycling. Journal of Strength Condition Research, 28, 2927-2936.

\section{Authors' note}

\section{Corresponding author}

Fabrício Azevedo Voltarelli, Ph.D.

Federal University of Mato Grosso

Fernando Corrêa da Costa Avenue, 2367, District: Boa Esperança

Postal Code: 78060-900

Cuiabá, MT, Brazil

Manuscript received on September 18, 2014

Manuscript accepted on August 19, 2015

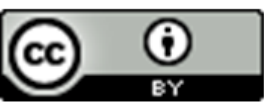

Motriz. The Journal of Physical Education. UNESP. Rio Claro, SP, Brazil - eISSN: 1980-6574 - under a license Creative Commons - Version 3.0 